\title{
Late Weichselian and Holocene biostratigraphy in borings southeast of Frederikshavn, Denmark.
}

\author{
KAREN LUISE KNUDSEN AND KJELL NORDBERG
}

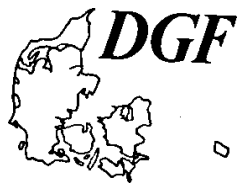

\begin{abstract}
Knudsen, K.L. and Nordberg, K.: Late Weichselian and Holocene biostratigraphy in borings southeast of Frederikshavn, Denmark. Bull. geol. Soc. Denmark, vol. 36, pp. 289-303. Copenhagen, December, 31st, 1987. https://doi.org/10.37570/bgsd-1988-36-10

Foraminifera, pollen, and molluscs have been investigated in marine Late Weichselian and Holocene deposits from borings southeast of Frederikshavn. The results from the different biostratigraphical methods are co-ordinated.

At least $14 \mathrm{~m}$ of sediments seem to be represented from the Younger Dryas Chronozone, and the thickness of the Holocene varies from 9 to $14 \mathrm{~m}$ in the three borings. The base of the Holocene occurs between 23.5 and $28.5 \mathrm{~m}$ below present day sea-level. A thin unit from the Boreal or possibly the Preboreal Chronozone seems to exist in two of the borings, but a considerable hiatus occurs between this and marine Subboreal and Subatlantic deposits in the study area.
\end{abstract}

K.L. Knudsen, Department of Micropalaeontology, Institute of Geology, University of Aarhus, DK-8000 Arhus C, Denmark. K. Nordberg, Department of Geology, Chalmers University of Technology/University of Göteborg, S-412 96 Gothenburg, Sweden. June, 6th, 1987.

\section{Introduction}

Little is known about the Late Weichselian and Holocene depositional history of the Kattegat region. Fält (1982) examined the foraminiferal stratigraphy of Late Weichselian and Holocene sediments off the west coast of Sweden, but was unable to establish an exact chronostratigraphy. More recently Larsen et al. (1986) have investigated the submarine Quaternary deposits of Læsø Rende in the western Kattegat (fig. 1). Here marine Holocene deposits rest on an abrasion surface which cuts across a complex of Late Weichselian marine sediments and glacial deposits. The stratigraphical relationships of these marine deposits were, however, not taken into consideration in that investigation.

The present three borings were undertaken by the Danish Geotechnical Institute in an area SE of Frederikshavn at water depths of between 13.8 and $16.4 \mathrm{~m}$ (figs. 1 and 2). The position of the borings and the level of the Weichselian-Holocene boundary here suggested the possibility of finding a complete marine sequence across this boundary (see Mörner 1969; Fält 1982, fig. 16a).

A detailed foraminiferal stratigraphy was made on two of the borings, and the molluscs were also registered. Pollen analyses on the same material made a chronostratigraphical interpretation possible.

Similar more regional studies of marine Late Weichselian-Holocene deposits and their relation to hydrographical changes are being made in the southern and eastern Kattegat by Nordberg and Bergsten (in prep.).

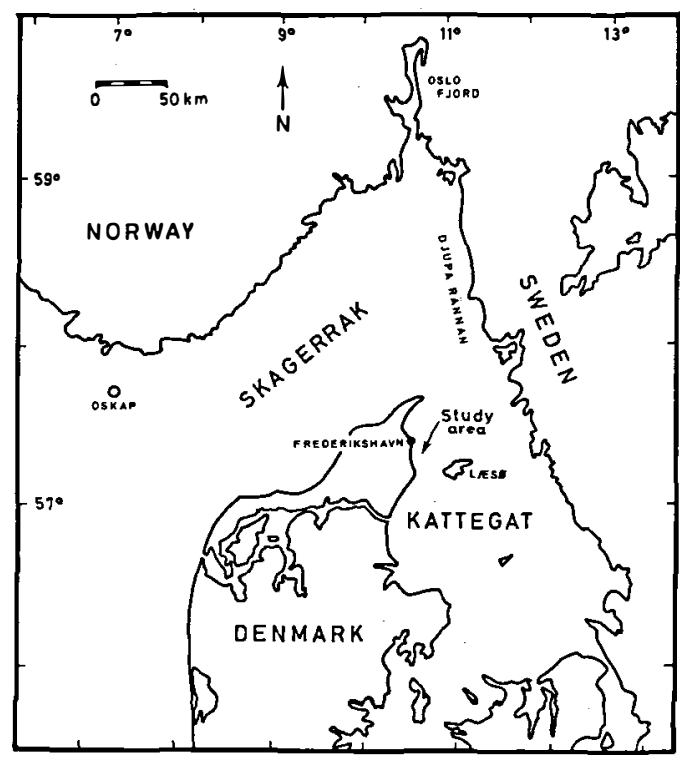

Fig. 1. Locality map. 


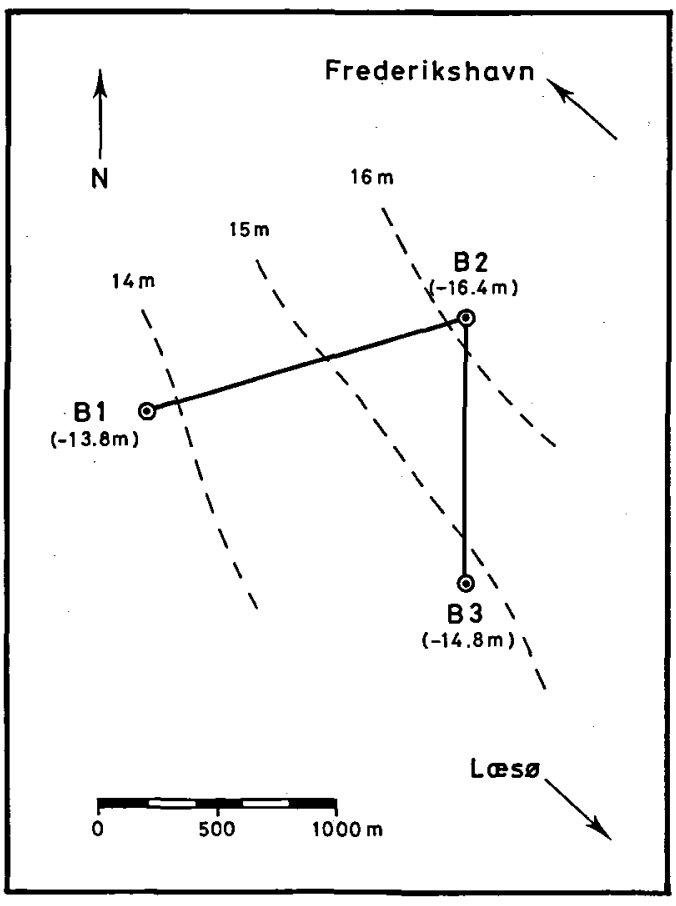

Fig. 2. The bore sites southeast of Frederikshavn.

\section{Material and methods}

The material used in the present study comprised partly of undisturbed core samples and partly samples taken with an open auger (see tables 1 and 2). The risk of downcore contamination in the latter material made it unsuitable for pollen analysis, but the foraminiferal faunas and molluscs were registered in both types of sample.

Samples for foraminiferal analyses were treated according to the laboratory methods described by Feyling-Hanssen et al. (1971) and Meldgaard and Knudsen (1979). The percentage frequencies of the most common foraminiferal taxa found in borings 2 and 1 are shown in figs. 4 and 5 , respectively. Only 9 core samples were available from boring 3 . The depth and stratigraphic interpretation of these samples are shown in the cross-correlation diagram, fig. 8.

The molluscs have been grouped in accordance with Antevs (1928) in figs. 4b and 5b.

All the samples for pollen analyses were treated using the filtration/density separation method described by Påsse (1985), complemented with standard methods (Assarsson and Granlund 1924; Erdtman 1960).
Pollen concentrations in the Frederikshavn borings were generally very low. Pre-Quaternary palynomorphs were present throughout both cores but were not counted and are not presented in the diagrams. Reworked Quaternary pollen and spores were included in the sum of primary deposited grains, because of the difficulty of objectively distinguishing between them (Stanley 1966). The pollen diagrams (figs. 6 and 7) were constructed as total diagrams where a uniform percentage scale was used for all taxa. All types of pollen were included in the pollen sum except for pollen from aquatic plants, spores, and algae, which have been calculated separately. A selection of the most frequent and important pollen, spores, and algae are given in the diagrams.

Local Pollen Assemblage Zones (LPAZ) were established in accordance with Hedberg (1976). Chronostratigraphical terms in this paper are used in accordance with Mangerud et al. (1974) and Mangerud and Berglund (1978), and they are based on results presented by Iversen (1967), Berglund (1966, 1969), and Andersen (1984). All zone boundaries were established by equally dividing the unit between two samples representing different zones. This procedure may cause some small discrepancies between pollen- and foraminiferal zone boundaries because of the different sampling intervals used.

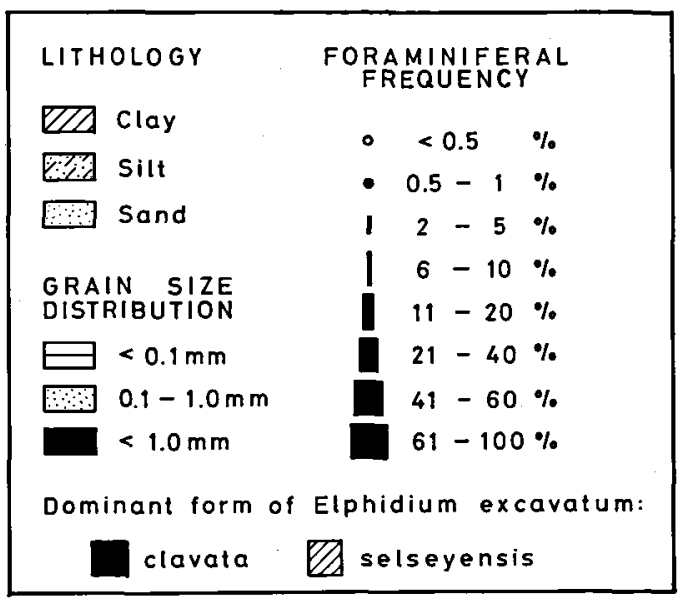

Fig. 3. Legend for figs. 4 and 5. 
Table 1. Lithology, Frederikshavn 1

Sample Lithology
no.
(C=core
spl.)

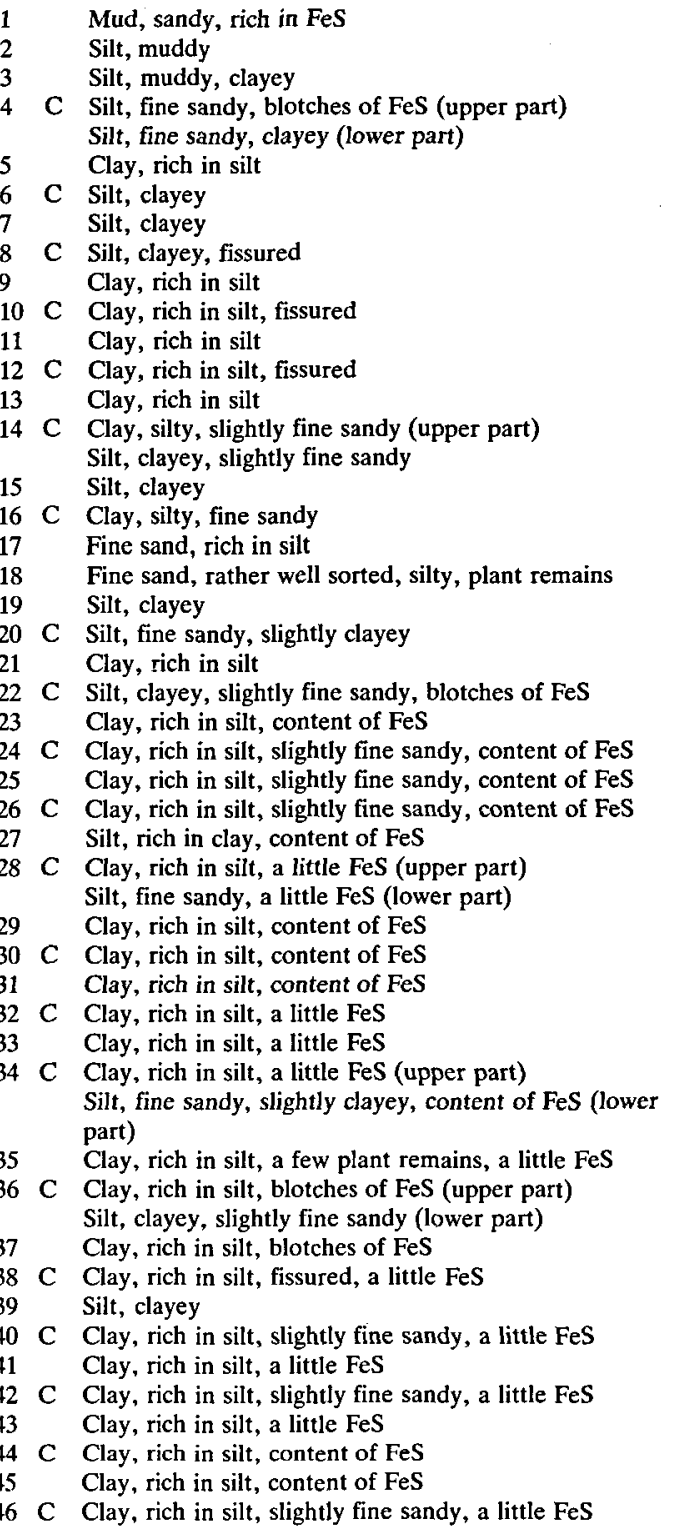

\section{Lithology}

Tables 1 and 2 contain a sediment description for each sample from Frederikshavn 1 and 2. The cored samples are marked with a $\mathrm{C}$ in the left column.

\section{Foraminiferal stratigraphy}

\section{Frederikshavn 2}

The water depth at the Frederikshavn 2 bore site was $16.4 \mathrm{~m}$, and the boring was $20.5 \mathrm{~m}$ deep. The marine sequence has been subdivided into 5 local foraminiferal assemblage zones (2:1 to $2: 5$ ), which are established in accordance with Hedberg (1976). The faunal characteristics of each of these zones are described below and shown in figs. $4 \mathrm{a}$ and $4 \mathrm{~b}$.

Eight samples are included in the lowest assemblage zone 2:1 (the Elphidium excavatum-

Table 2. Lithology, Frederikshavn 2

\begin{tabular}{l} 
Sample Lithology \\
no. \\
(C=core \\
spl.) \\
\hline
\end{tabular}

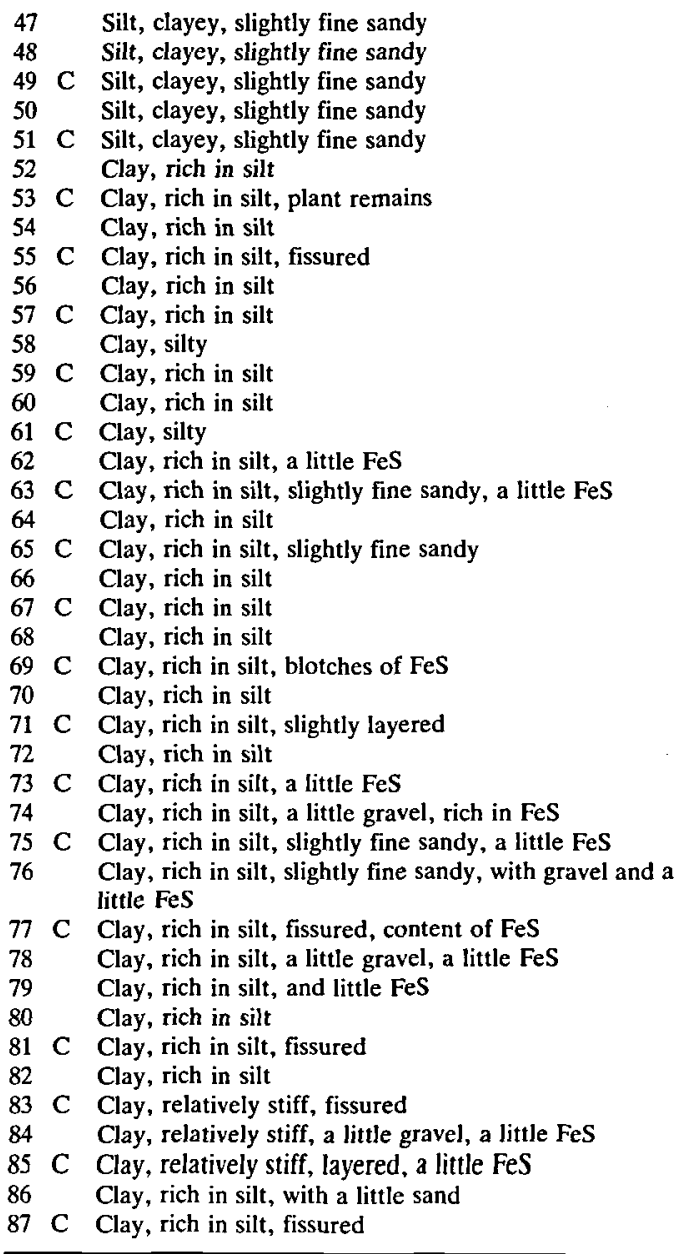




\section{FREDERIKSHAVN 2}

\begin{tabular}{|c|c|c|c|c|c|c|c|c|c|c|c|c|c|c|c|c|c|c|c|c|c|c|c|c|c|c|c|c|c|c|}
\hline 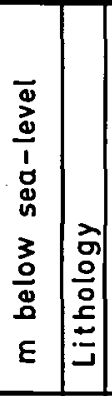 & 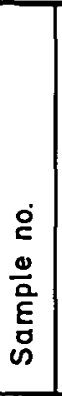 & 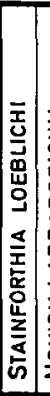 & 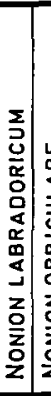 & & 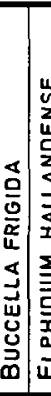 & & 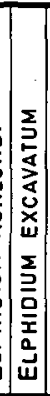 & & 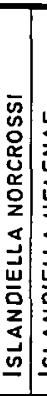 & 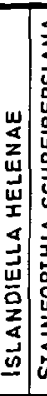 & & 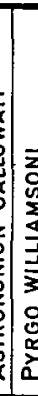 & & 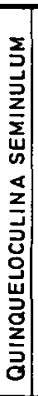 & 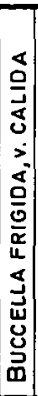 & 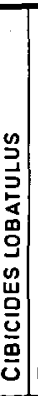 & 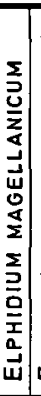 & 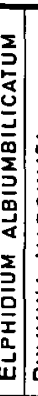 & & & 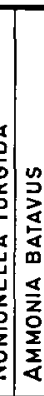 & & 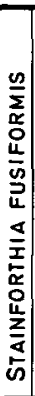 & $\begin{array}{l}\mathbf{x} \\
\mathbf{2} \\
\mathrm{u} \\
\mathbf{\Sigma}\end{array}$ & $\begin{array}{l}\bar{x} \\
\bar{y} \\
\end{array}$ & 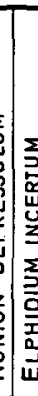 & & 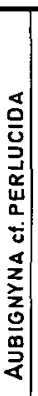 & & $\begin{array}{l}\text { 동 } \\
\stackrel{0}{0} \\
\text { 옹 }\end{array}$ \\
\hline & 47 & & 0 & & & & & & & & & & & & & 0 & I & $\bullet$ & & 1 & 1 & ० & I & & • & $\cdot$ & &. & & \\
\hline & $48-$ & & 0 & & & & & & & & & & & 0 & 0 & $\circ$ & 1 & 1 & & 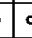 & & 0 & - & & - & 1 & & 1 & & \\
\hline $18-$ & $49-$ & & 0 & & & & & & & & & & & $\circ$ & & $\circ$ & $I$ & $\cdot$ & & c & & 0 & I & - & •t & $\circ$ & & $\bullet$ & & \\
\hline 7 & $50-$ & & $\circ$ & & $\circ$ & & & $\circ$ & & & & & & - & 0 & $\circ$ & 1 & 0 & & 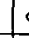 & & $\circ$ & $\circ$ & - & 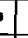 & 1. & & $\cdot$ & & \\
\hline 9 & $51-1$ & & - & & & & & & & & & & & $\cdot$ & 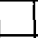 & 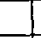 & 1 & .1 & & 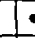 & & $\circ$ & 1 & - & 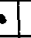 & . & & $\cdot$ & & \\
\hline$E$ & $52-$ & & 0 & & & & & & & & & & & $\circ$ & 0 & & &. & 1 & 2 & 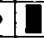 & 1 & I & 。 & 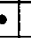 & $\bullet$ & & $\bullet$ & & \\
\hline $20 \pm$ & $53-$ & & - & & & & & & & & & $\circ$ & & $\circ$ & & $\circ$ & & - & & 5 & 1 & I & $\bullet$ & - & $\circ$ & $\cdot$ & & 1 & & \\
\hline & $54-$ & 0 & $\bullet$ & & & & & & & & & & & & - & & 1 & I & & o & & 1 & - & $\bullet$ & $\bullet$ & $\bullet$ & & 1 & & \\
\hline & $55-$ & $\bullet$ & & & & & & & & & & & & 0 & & 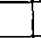 & 1 & $\cdot$ & & -7. & 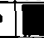 & I & 0 & ० & - & 1. & & 1 & & \\
\hline$\because$ & $56-$ & 0 & & & & & & & & & & & & $\circ$ & & $\circ$ & $\cdot$ & & & 1 & 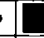 & 1 & 0 & 0 & 0 & 10 & I & $\cdot$ & b & $2: 5$ \\
\hline $22-1$ & $57-$ & 0 & $\circ$ & & & & & $\circ$ & & & & & & $\circ$ & 0 & & 1 & $\cdot$ & & & 1 & I & 0 & 0 & 。 & 0 & & $\cdot$ & & \\
\hline & $58-$ & $\bullet$ & $\circ$ & & & & & & & & & & & $\circ$ & & $\bullet$ & 1 & - & & & & & $\cdot$ & - & $\circ$ & 0 & & 1 & & \\
\hline & $59-$ & 0 & & & & & & $\circ$ & & & & & & & $\cdot$ & $\circ$ & $\cdot$ & $\circ$ & & 1 & & & $\circ$ & - & $\circ$ & 1 & $\circ$ & $\circ$ & & \\
\hline & $60-$ & $\circ$ & & & & & & & & & & & & & $\cdot$ & 0 & 1 & $\cdot$ & & I & 1 & & $\cdot$ & 0 & 0 & 0 & 0 & $\cdot$ & & \\
\hline $24-7=$ & $61-$ & & & & & & & $\cdot$ & & & & & & & 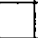 & & $\cdot$ & 0 & & 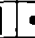 & 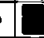 & 1 & 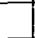 & & 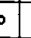 & 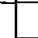 & $\circ$ & & & \\
\hline 13 & $62-$ & & & & & & & $\bullet$ & & & & & & & 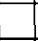 & & 0 & 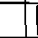 & & 11 & 1. & 8 & $\bullet$ & 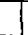 & 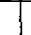 & 1 & 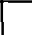 & & & \\
\hline & 63- & 0 & & & & & & $\circ$ & & & & & & & 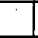 & & $\cdot$ & 0 & & 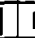 & 1 & $\bullet$ & - & 0 & 。 & 0 & - & & & \\
\hline & $64-1$ & & & $\circ$ & $\circ$ & & & $\circ$ & & & & & & & $\circ$ & $\cdot$ & $\cdot$ & $\cdot 1$ & & 1. & D & 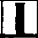 & 0 & 0 & $\circ$ & 0 & 1 & & 0 & \\
\hline $26->$ & $65-$ & $\bullet$ & 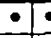 & 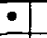 & $\cdot$ & $\circ$ & & - & & t & - 0 & 0 & & & -1 & $\circ$ & & 1 & I & 21 & 1 & & $I$ & $\bullet$ & - & $\cdot$ & - & & & $2: 4$ \\
\hline & 65- & 0 & - & $\bullet$ & 1 & I & & & & 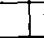 & 1 & & 0 & & 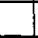 & & 1 & II & & - & 1 & $\bullet$ & 0 & & & $I$ & 0 & & & \\
\hline & $67-$ & & $\circ$ & $\bullet$ & $I$ & $\circ$ & & & & & 1 & & & $\circ$ & $\cdot$ & 0 & 1 & I & & & & & & & & & 。 & & & \\
\hline & $68-$ & & \begin{tabular}{l|l} 
I & 1 \\
\end{tabular} & I & I & I & & & & & $1 \cdot$ & . & - & & & $\circ$ & 1 & 1 & • & & 1 & & & & & & & & & \\
\hline $28-$ & $69-$ & $\cdot$ & I 1 & I & I & I & & 1 & & & 1. & 10 & $\bullet$ & 0 & $\circ$ & $\circ$ & 1 & 1. & 。 & (c) & \begin{tabular}{|l|l} 
& 0 \\
\end{tabular} & & & & & $\circ$ & & & & \\
\hline & $70-$ & 0 & 1 & 1 & - & 1 & & 1 & 0 & & i) & 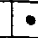 & 1 & 0 & & $\cdot$ & 1 & 1 & 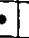 & & 0 & & & & & & & & & $2: 3$ \\
\hline$-1=$ & 71. & 0 & 1 & - & 1 & $\bullet$ & & & & & 10 & & $\circ$ & & 0 & 0 & I & I & 0 & & 0 & & & & & & & & & \\
\hline$E$ & $72-$ & $\cdot$ & I & 1 & 1 & $\bullet$ & & & & .1 & 10 & 0 & 1 & & $\cdot$ & & I & 1 & 1 & 1 & 0 & 0 & & & & & 。 & & & \\
\hline $30-2$ & 73 & & $\bullet$ & I & $\cdot$ & $\circ$ & & & & 0 & 10 & 0 & 0 & & 1 & $\circ$ & 1 & 1 & & & 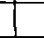 & & & & & & & & & \\
\hline 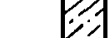 & $74-$ & 0 & & $\therefore$ & I & $\div$ & & & 0 & 0 & $1 \bullet$ & & 1 & & $\circ$ & 1 & 1 & $\circ$ & & & $\circ$ & & & & & & & & & \\
\hline$F \%$ & $75-$ & 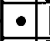 & & & $\circ$ & 10 & & & 0 & $\circ$ & 0 & 0 & & 0 & $\bullet$ & $\circ$ & I & $\circ$ & 6 & & & & & & & & & & & \\
\hline & $76-$ & $\cdot$ & & & & $\cdot$ & & & $\circ$ & 0 & \begin{tabular}{l|l}
0 & 1 \\
0
\end{tabular} & & 0 & 0 & & $\cdot$ & 1 & 0 & & & & & & & & & & & & $\therefore 7$ \\
\hline $32-7$ & $77-1$ & 5 & 1 & & & 0 & & & $\circ$ & $\cdot 1$ & - 0 & 0 & 0 & 0 & & & 1 & & & & & & & & & & & & & \\
\hline & $78-$ & $\cdot$ & & $\circ$ & $\circ$ & $\circ$ & & & $\circ$ & 0 & $\circ$. & • & - & 0 & 0 & $\circ$ & $\mathbf{I}$ & $\circ$ & 0 & & & & & & & & & & & \\
\hline & $79-$ & 0 & & & 0 & $\circ$ & & & 0 & .1 & . 0. & 10 & 0 & 1 & 0 & $\cdot 1$ & 1 & & & & 10 & & & & & & & & & \\
\hline & $80-1$ & $\cdot$ & 1 & & 0 & $\circ$ & & & & . & - 0 & 0 & & 0 & 0 & 01 & \begin{tabular}{l|l}
1 \\
\end{tabular} & & & & 10 & & & & & & & & & \\
\hline $34-Y \%$ & $81-$ & $\circ$ & 1 & & 0 & 0 & & & $\circ$ & & 0 & & & $\circ$ & $\cdot$ & $\circ$ & $\circ$ & $\circ$ & & & $\circ$ & & & & & & & & & \\
\hline r & $82-$ & $\cdot$ & I & & $\circ$ & & & & 01 & 0 & 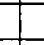 & 0 & & $\bullet$ & 0 & 0 & $\bullet$ & 0 & & & 10 & & & 。 & & & & & & \\
\hline 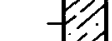 & $83-$ & 0 & 1 & & $\circ$ & 。 & & & & & 0 & & & $\bullet$ & & & $\cdot$ & $\cdot$ & & & & & & & 。 & & & & & 2,1 \\
\hline & $84-$ & \begin{tabular}{|l|}
1 \\
\end{tabular} & 1 & & $\circ$ & & & & & $\circ$ & & & & $\circ$ & 0 & & $\circ$ & & & & & & & & & & & & & \\
\hline $36-$ & $85-$ & 0 & I & 0 & & 。 & & & & .1 & 。 & 1 & & $I$ & $\cdot$ & $\circ$ & 0 & 0 & - & & & & & & & & & & & \\
\hline & $86-$ & & 2 & & & 1 & & 8 & & & & & & & & 1 & & 1 & & & & & & & & & & & & \\
\hline & 87- & . & 0 & $\cdot 1$ & 10 & & & & • & & $\bullet$ & & & & 1 & 0 & $\cdot 1$ & & $\begin{array}{ll} \\
\end{array}$ & 。 & & & & & 01 & & & & & \\
\hline
\end{tabular}

Fig. 4a. Range chart for Frederikshavn 2 with frequency distribution of selected foraminiferal taxa. Legend in fig. 3. 
FREDERIKSHAVN 2

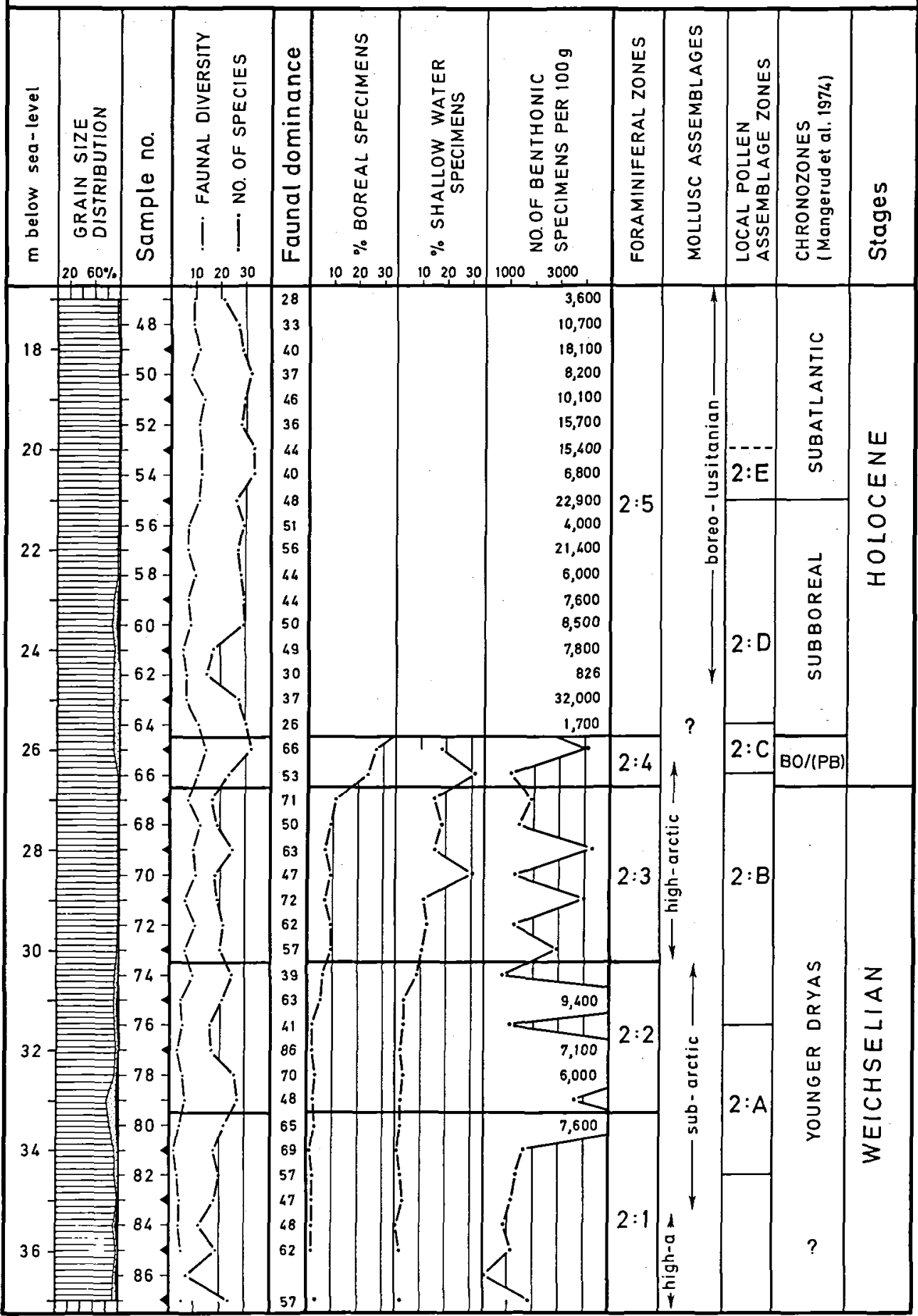

Fig. 4b. Frederikshavn 2, palaeoenvironmental indices and correlation. Cored samples are marked with triangles. 
Cassidulina reniforme zone). Elphidium excavatum, forma clavata (see Feyling-Hanssen 1972) and Cassidulina reniforme totally dominate the faunas, and Nonion labradoricum is the only important accessory species $(0.5-10 \%)$. The faunal diversity index (Walton 1964) is very low (2-5). Boreal species are nearly absent $(1-3 \%)$, and the influence of shallow water taxa is low as well $(<0.5-3 \%)$. The assemblages indicate high-arctic conditions, a water depth of at least $20 \mathrm{~m}$, and normal marine salinities (Buzas 1965).

Cassidulina reniforme decreases in importance in assemblage zone 2:2 (the Elphidium excavatum-Nonion labradoricum zone) (between -33.0 and $-30.5 \mathrm{~m}$ ), while there is a marked increase in $N$. labradoricum. The faunal diversity index is still low, and environmental conditions cannot have been much different from those in zone 2:1. A slight increase in faunal diversity, as well as in the percentage of both boreal and shallow water species at the top of the zone (fig. 4b), may reflect a transition to ameliorated conditions and/or shallower waters.

The influence of Nonion labradoricum decreases again in assemblage zone $2: 3$ (the $E l$ phidium excavatum-Elphidium hallandense zone) $(-30.0$ to $-27.0 \mathrm{~m})$. Stainforthia schreibersiana becomes an important element in the faunas, together with a number of other accessory species such as the arctic shallow water taxa Nonion orbiculare, Elphidium hallandense, and E. asklundi. Elphidium magellanicum and E. albiumbilicatum are also more common. These two species usually occur in boreal waters, but they can also tolerate extremely low salinities (Lutze 1965; Knudsen 1982). Including the two species in the boreal content this becomes $7-11 \%$ in zone $2: 3$, and the content of shallow water specimens rises to between 10 and $30 \%$ (fig. $4 \mathrm{~b}$ ). Less severe environmental conditions would, thus, appear to have existed during zone $2: 3$, as is also indicated by the presence of a higher faunal diversity (612) than in the previous zones.

Only two samples (66 and 65) are allocated to assemblage zone 2:4 (the Elphidium excavatumElphidium magellanicum zone). The foraminiferal assemblages contain many boreal specimens. In addition to those found in the previous zone i.a. Bulimina marginata, Nonionella turgida, Ammonia batavus, and Elphidium incertum also occur here (fig. 4a). The total boreal content is 24 and $27 \%$ in zone $2: 4$, and the influence of shallow water specimens is also considerable (fig. 4b).

Assemblage zone 2:5 (the Ammonia batavusElphidium excavatum zone) comprises the upper c. $9 \mathrm{~m}$ of the boring $(-25.5$ to $-17.0 \mathrm{~m})$. The faunas are boreal, with Ammonia batavus, Bulimina marginata, and Elphidium excavatum, forma selseyensis among the most frequent species. The high percentages of $B$. marginata, Textularia sagittula, and Hyalinea balthica at the base of the zone suggest an initial water depth of at least $20-30 \mathrm{~m}$. The gradual decrease in frequency of the latter species and the subsquent increase in Nonion germanicum, $N$. depressulum, and Eggerella scabra in the upper part of the zone indicate a shallowing in water towards the present $16.8 \mathrm{~m}$ depth. The sharp rise in the numbers of Eggerella scabra at the top of the boring may, however, partly be a result of preservation of the arenaceous tests. The tests are badly damaged at its first appearance, but are well preserved in the uppermost samples.

\section{Frederikshavn 1}

The water depth at the Frederikshavn 1 bore site was $13.8 \mathrm{~m}$, and the boring was $23.2 \mathrm{~m}$ deep. The marine sequence has been subdivided into three foraminiferal assemblage zones $(1: 2,1: 3$, and $1: 5$; figs. $5 \mathrm{a}$ and $5 \mathrm{~b}$ ). These zones are briefly described below, and a correlation with the corresponding zones of the Frederikshavn 2 boring is suggested (fig. 8).

The lowermost 7 samples comprises the assemblage zone 1:2 (the Elphidium excavatumNonion labradoricum zone). The faunas correspond closely to the arctic zone $2: 2$ faunas of boring 2 . In addition, the same minor increase in the proportion of boreal species as occurred at the top of zone 2:2 is also present at the top of zone 1:2 (fig. 5b). An Elphidium excavatum-Cassidulina reniforme zone, as found at the bottom of boring 2 , is not reached in boring 1 .

Samples 39 to 19 are included in assemblage zone 1:3 (the Elphidium excavatum-Elphidium hallandense zone). The arctic to sub-arctic composition of the faunas can be compared to that found in zone 2:3 of boring 2 , but the zone is much thicker here (fig. 8).

A unit corresponding to zone $2: 4$ at Frederikshavn 2 has not been registered in boring 1 . 
The upper 18 samples are referred to assemblage zone 1:5 (the Ammonia batavus-Elphidium excavatum zone). The faunas are similar to those found in the boreal zone $2: 5$ of boring 2 , but depths were constantly shallower at boring 1 . Bulimina marginata is for instance less frequent and Nonion germanicum occurs throughout the zone. Nevertheless, the faunas indicate water depths of at least $20 \mathrm{~m}$ at the base of this zone. The increase in percentages of Eggerella scabra towards the top is similar to that found at boring 2.

\section{Frederikshavn 3}

The water depth at the Frederikshavn 3 bore site was $14.8^{\circ} \mathrm{m}$, and the boring was $40.0 \mathrm{~m}$ deep. Only 9 samples, which were all cores, were made available for foraminiferal analysis. The faunas in these samples were, however, easily correlatable with the assemblages known from borings 1 and 2. The correlation is shown in fig. 8 .

The lower four samples were extracted from relatively stiff clays with a content of FeS. They contain Elphidium excavatum-Cassidulina reniforme faunas with some Nonion labradoricum in The upper part This assemblage zone 3:1 can, therefore, be correlated with zone $2: 1$ of boring 2.

The next two samples, a silty clay and a clayey silt, belong in an Elphidium excavatum-Elphidium hallandense zone, assemblage zone 3:3. An Elphidium excavatum-Nonion labradoricum zone was not found,but such a zone could easily have escaped sampling here (fig. 8).

One sample from a thin layer of fine well sorted sand and silty clay at a level of $-28.5 \mathrm{~m}$ did not contain any foraminifera. A pyritized echinoid occurred at this level.

A slightly fissured silty clay at $-25.5 \mathrm{~m}$ contains an Elphidium excavatum-Elphidium magellanicum zone fauna, assemblage zone $3: 4$, corresponding to zone $2: 4$ of boring 2 .

The lowermost part of an Ammonia batavusElphidium excavatum zone fauna, assemblage zone $3: 5$, is also represented by only one sample. This is a slightly fissured silty clay with a foraminiferal fauna exactly similar to those found in zones $2: 5$ and $1: 5$ of borings 2 and 1 (fig. 8).

\section{Pollen stratigraphy}

Pollen analyses from two borings have been used to establish local pollen assemblage zones (LPAZ) that reflect major events in the vegetational history of the Kattegat region (Fries 1951; Robertsson 1982; Heusser 1983). The pollen stratigraphy is correlated with pollen analytical investigations performed by several authors on the surrounding land areas. Those investigations were compiled and summarized by Iversen (1967). The sparce frequency of samples and the limiting factors affecting pollen analysis of marine minerogenic sediments (see Robertsson 1982) call upon a great deal of caution in interpreting the diagrams.

\section{Frederikshavn 2 (fig. 6)}

The core has been subdivided into five LPAZ. The stratigraphic record seems to be incomplete, at least at two levels, between sampe numbers $65-67$ and $63-65$, respectively. The preservation of the pollen grains is generally poor below $26 \mathrm{~m}$.

\section{LPAZ 2:A Pinus (34/35-31/32 m)}

Pinus is strongly represented, and all other taxa are only of minor importance in this LPAZ. The pollen spectra seems to reflect an effect of sediment dynamics and sorting, rather than the actual inland vegetation. Pollen concentrations below $32 \mathrm{~m}$ in Frederikshavn 2 are extremely low. The chronostratigraphical interpretation is, therefore, somewhat uncertain, but the zone seems to correspond to the Younger Dryas Chronozone.

\section{LPAZ 2:B Pinus-Betula-Juniperus-Artemisia (31/32-26/27 m)}

Pinus dominates over Betula and is strongly represented in the upper part of the zone. Small maxima of Juniperus and Empetrum are present. Salix, Calluna, Caryophyllaceae, and Chenopodiaceae also occur.

Cyperaceae and Poaceae have relatively low percentages and decrease slightly upwards. Polypodiaceae increase slightly in importance. Fluctuating, high frequencies of Pediastrum are pronounced within the zone. Corylus, Alnus, Polypodiaceae, and to a minor extent Quercus, Ulmus, and Tilia are represented. These taxa 
FREDERIKSHAVN 1

\begin{tabular}{|c|c|c|c|c|c|c|c|c|c|c|c|c|c|c|c|c|c|c|c|c|c|c|c|c|c|c|c|c|}
\hline 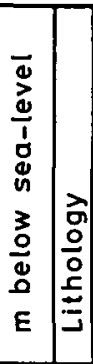 & \begin{tabular}{|l} 
\\
\\
$\circ$ \\
$c$ \\
$\frac{a}{a}$ \\
E \\
in
\end{tabular} & 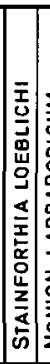 & 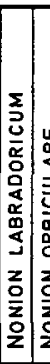 & 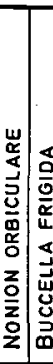 & 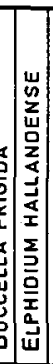 & 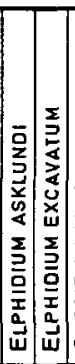 & 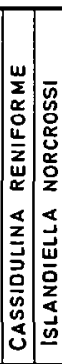 & 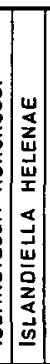 & 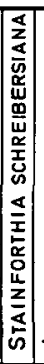 & & & 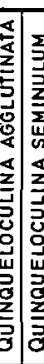 & 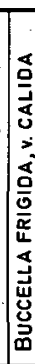 & & & 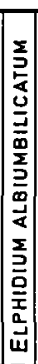 & & & 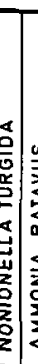 & 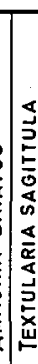 & 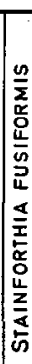 & & & & 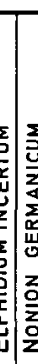 & & 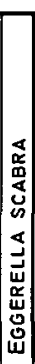 & 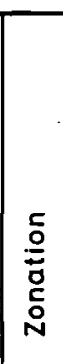 \\
\hline \multirow{11}{*}{$18-$} & 1 & & & 0 & & & & & & & & 10 & 10 & 0 & $\pi$ & 1 & 0 & & & 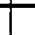 & & 1 & 0 & 7 & - & \multicolumn{2}{|c|}{01} & \multirow{18}{*}{$1: 5$} \\
\hline & 2 & & & & & & & & & & & & & & I & 1 & 0 & & & & - & 0 & & 1 & 1 & & & \\
\hline & 3 & & & & & & & & & & & & 10 & 0 & 1 & - & 0 & & & & 1 & $\bullet$ & $\cdot$ & - & 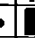 & & 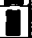 & \\
\hline & 4 & $\cdot 0$ & 0 & 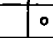 & & 16 & & & & & & 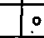 & & & 1 & 1 & 1 & & $\circ$ & & 1 & $\cdot$ & 。 & .. & $\cdot$ & & & \\
\hline & 5 & \begin{tabular}{l|l}
$\circ$ \\
\end{tabular} & $\begin{array}{l} \\
\end{array}$ & & & & 0 & & & & & & $\cdot$ & 0 & 1 & 1 & 1 & & .11 & $\circ$ & 1 & - & $\div$ & 1. & t & $\bullet$ & I & \\
\hline & 6 & & $\bullet$ & & & & $\cdot$ & & & & & $\cdot$ & & $\cdot$ & $I$ & 1 & & - & $\cdot$ & $\bullet$ & $\bullet$ & $\cdot$ & $\cdot$ & I & of & & 1 & \\
\hline & 7 & 0 & 0 & & & 音 & . & & & & & . & 。 & & 1 & 1 & & . & $\circ$ & $\circ$ & $\bullet$ & - & $\cdot$ & - & it & - & 1 & \\
\hline & 8 & & 0 & & & 1 & & & & & $\circ$ & & • & & 1 & $\bullet$ & & & $\bullet$ & I & • & $\cdot$ &. & 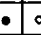 & 01 & I & $\circ$ & \\
\hline & 9 & 0 & & $\circ$ & & & & & & & & $\circ$ & 0 & & 1 & -1 & & & - & 1 & & 0 & $\circ$ & $\circ 0$ & $\circ$ & & 0 & \\
\hline & 10 & & & & & & $\begin{array}{ll} \\
\end{array}$ & & & & & . & & - & 1 & $\bullet$ & & $\cdot$ & $\circ$ & I & & $\cdot$ & I & & & - & & \\
\hline & 11 & $\circ$ & & & & & & & & & & & $\circ$ & & - &. & & $\circ$ & $\circ$ & 1 & & - & $\circ$ & $\circ$ & 1 & 1 & & \\
\hline $20-\%$ & 12 & $\circ$ & & & & II & 0 & & & & & . & • & $\circ$ & 1 & - & & - & 1 & 1 & 0 & 0 & 1 & $\cdot 0$ & 01 & & $\circ$ & \\
\hline & 13 & & & & & & & & & & & 10 & • & & $I$ & 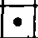 & & $\cdot$ & -8 & 1 & & 0 & 1 & & 1 & $\cdot$ & & \\
\hline & 14. & .0 & & & & & & & & & & & • & & 1 & $\bullet$ & & 0 & 11 & T & $\cdot$ & - & 1 & - 0 & . & $\circ$ & & \\
\hline & 15. & $\circ$ & & $\circ$ & & & & & & & & $\circ$ & 0 & 0 & I & 1 & & $\cdot$ & : & 1 & $\cdot$ & 0 & $\circ$ & - & 1 & & $\circ$ & \\
\hline $22-$ & 16 & $\cdot 1$ & 0 & 10 & & & & & & & & 10 & 。 & & 1 & . & & I & 1 & 1 & & 0 & - & $\bullet$ & 1 & . & & \\
\hline & 17 & & - & . & & & $\cdot$ & & & \begin{tabular}{l|l} 
& 0 \\
\end{tabular} & & $\bullet$ & 1 & & II & 1 & 1 & $\circ$ & $\cdot 1$ & • & I & - & $\circ$ & • & 1 & & 0 & \\
\hline & 18 & \begin{tabular}{|l|l}
. & \\
\end{tabular} & .00 & $\circ$ & & & . & & & \begin{tabular}{l|l} 
\\
\end{tabular} & & .. & . & & 1 & I & $\pi$ & $\circ$ & $\cdot 1$ & 1 & 1 & . & - & $\cdot$ & 1 & $\cdot$ & & \\
\hline & 19 & 0 & $\cdot 0$ & \begin{tabular}{l|l}
0 & \\
\end{tabular} & 1 & - & & & & & & $0 \%$ & • & & 1 & 1 & $\circ$ & & 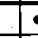 & & & 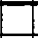 & 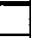 & 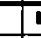 & 1 & & & \\
\hline $24-$ & 20 & $\begin{array}{ll}0 \\
\end{array}$ & $\cdot$ & .10 &. & & & & it & \begin{tabular}{|l|l}
$\circ$ & 0 \\
\end{tabular} & & .10 & • & 0 & & I & & & & & & & & & •t & & & \\
\hline & 21 & & $\cdot 0^{\circ}$ & .10 & 0.1 & 1 & & & i) & & & - & • & 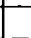 & $\pi$ & $\pi$ & $\circ$ & & s & & & & & T & 1 & & & \\
\hline & 22 & & \begin{tabular}{l|l}
10 \\
\end{tabular} & - & 1 & 1 & & & 1 & 100 & .0 & $\circ$ & 10 & & $\pi$ & & $\circ$ & & & & & & . & 7 & $\cdot$ & & & \\
\hline & 23 & & \begin{tabular}{l|l}
$\circ$ & 0 \\
\end{tabular} & 0 & $\bullet$ & 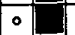 & & & 11 & \begin{tabular}{l|l}
0 \\
\end{tabular} & 10 & $\begin{array}{lll}0 & 0\end{array}$ & 1 & $\bullet$ & $\pi$ & & & $\circ$ & & & & 0 & & & 10 & & & \\
\hline 26 & 24 & & $\cdot \cdot$ & - 10 & & 0 & & & 0 & 0 & & & 1 & & 1 & &. & & 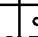 & & & & $\circ$ & 7 & 1 & & & \\
\hline & 25 & 0 & $\circ 1$ & 1 & $\bullet$ & \begin{tabular}{|l|} 
\\
\end{tabular} & & & 1 & 0 & & 0 & 10 & & 1 & & & & & & & & & I & 10 & & & \\
\hline & 26 & & $\circ$. & .10 & 1 & 0 & & & i & & & 0 & 10 & 0 & 1 & 11 & 0 & & & & & & & 7 & 7 & & & \\
\hline & 27 & & $\circ \quad 0$ & $\circ$ & 0 & 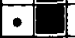 & & & 1 & & & . & 10 & 10 & 1 & 1 & 0 & & & & & & & I & & & & \\
\hline $28-$ & 28 & & 0.0 & $\cdot$ & 1 & $\bullet$ & I & & $\cdot$ & & & 0.0 & 10 & & 1 & 1 & & & & & & & & & & & & \\
\hline & 29 & & $\cdot 1$ & 1 & $\cdot 1$ & . & & & $T$ & 0 & 01 & I & 。 & & $\bullet$ & 1 & & & $\circ$ & & & & & & 0 & & & $1: 3$ \\
\hline & 30 & 10 & 0. & $\bullet$ & 01 & 10 & & & 1 & & & 00 & $\bullet$ & & $\pi$ & 1 & & & & & & & & 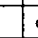 & 0 & & & \\
\hline & 31 & & 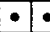 & $\bullet$ & 10 & 10 & & & $\pi$ & & & \begin{tabular}{l|l}
0 & 0
\end{tabular} & 。 & & 0 & 1 & & & & & & & & 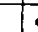 & 0 & & & \\
\hline $30-$ & 32 & & $\cdot \circ$ & $\bullet$ & 01 & 10 & & & i) & & & $\bullet$ & & & $\cdot$ & 1 & & & $\circ$ & & & & & & & & & \\
\hline & 33 & & \begin{tabular}{l|l}
11 \\
\end{tabular} & 1 & 1 & $\circ$ & & 0 & 1 & 0 & & 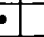 & 10 & & $\bullet$ & 1 & & & & & & & & 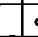 & $\circ$ & & & \\
\hline & 36 & & 0.0 & $\circ$ & $\bullet$ & ○ & & 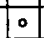 & I & 0 & 0 & $I$ & . & $\circ$ & 1 & & 0 & & $\circ$ & & & $\circ$ & & & & & & \\
\hline & 35 & $0 \mid$ & 10 & $\bullet$ & $\bullet$ & 。 & & & $\pi$ & \begin{tabular}{|l|l}
0 & 0 \\
\end{tabular} & $\circ$ & $\begin{array}{lll}\circ & 0\end{array}$ & 1 & 0 & 1 & 1 & & & 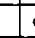 & & & 0 & & $\circ$ & & & & \\
\hline $32-$ & 36 & & \begin{tabular}{|l|l|l} 
& \\
\end{tabular} & $\bullet$ & \begin{tabular}{|l|l}
$I$ \\
\end{tabular} & 0 & & & 1 & .0 & 0. & - 10 & • & . & 1 & 1 & & & & & & & & & & & & \\
\hline & 37 & & $\cdot \bullet$ & . & $\bullet$ & & & & 1 & \begin{tabular}{l|l}
0 & \\
\end{tabular} & & & $\bullet$ & . & 1 & 1 & & & & & & & & $\circ$ & 0 & & & \\
\hline & 38 & & $\cdot$ & 10 & 1 & & & 0 & & $\cdot \mid$ & 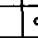 & ०. & 1 & • & $\circ$ & & & & 8 & & & 0 & & & & & & \\
\hline & 39 & & .0 & $\circ$ & $\cdot$ & $\cdot$ & & & 1 & \begin{tabular}{|l|l|l} 
& 0 \\
\end{tabular} & & - 10 & 8 & . & 1 & 1 & & $\circ$ & & & & 10 & & & $\cdot$ & & & \\
\hline $34-$ & 40 & 10 & & & & & 10 & & $\circ$ & $\begin{array}{ll}0 & 0 \\
\end{array}$ & 0 & 10 & $\bullet$ & 0 & 1 & $\bullet$ & 0 & & & & & & & & & & & \\
\hline & 41 & $\cdot$ & & & & & 10 & 10 & $\cdot 1$ & 1 & & 0.0 & $\bullet$ & • & 1 & 1 & & & & & & & & & & & & \\
\hline & 42 & $\bullet$ & & 0 & & & 0 & $\%$ & 1 & $\because$ & & ०. & 1 & & 1 & 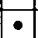 & & & & & & $\circ$ & 0 & & 070 & & & \\
\hline & 43 & & & - & & & & & $\circ$ & & & 10 & To & 。 & $\bullet$ & $\cdot$ & & & & & & $\circ$ & 0 & & & & & $1: 2$ \\
\hline & $44-$ & 50 & & $\circ$ & & & 0 & & 0 & & & 10 & 10 & & 1 & $\bullet$ & -0 & 0 & & & & & & & 0 & & & \\
\hline & 45 & & & 0 & & & & & & 0 & & $\circ$ & & & 11 & $\cdot$ & & & & & & & & & & & & \\
\hline & & & 1 & & & & $\bullet$ & & & & & & & & & 0 & & & & & & & & & & & & \\
\hline
\end{tabular}

Fig. 5a. Range chart for Frederikshavn 1 with the frequency distribution of selected foraminiferal taxa. Legend in fig. 3. 


\section{FREDERIKSHAVN 1}

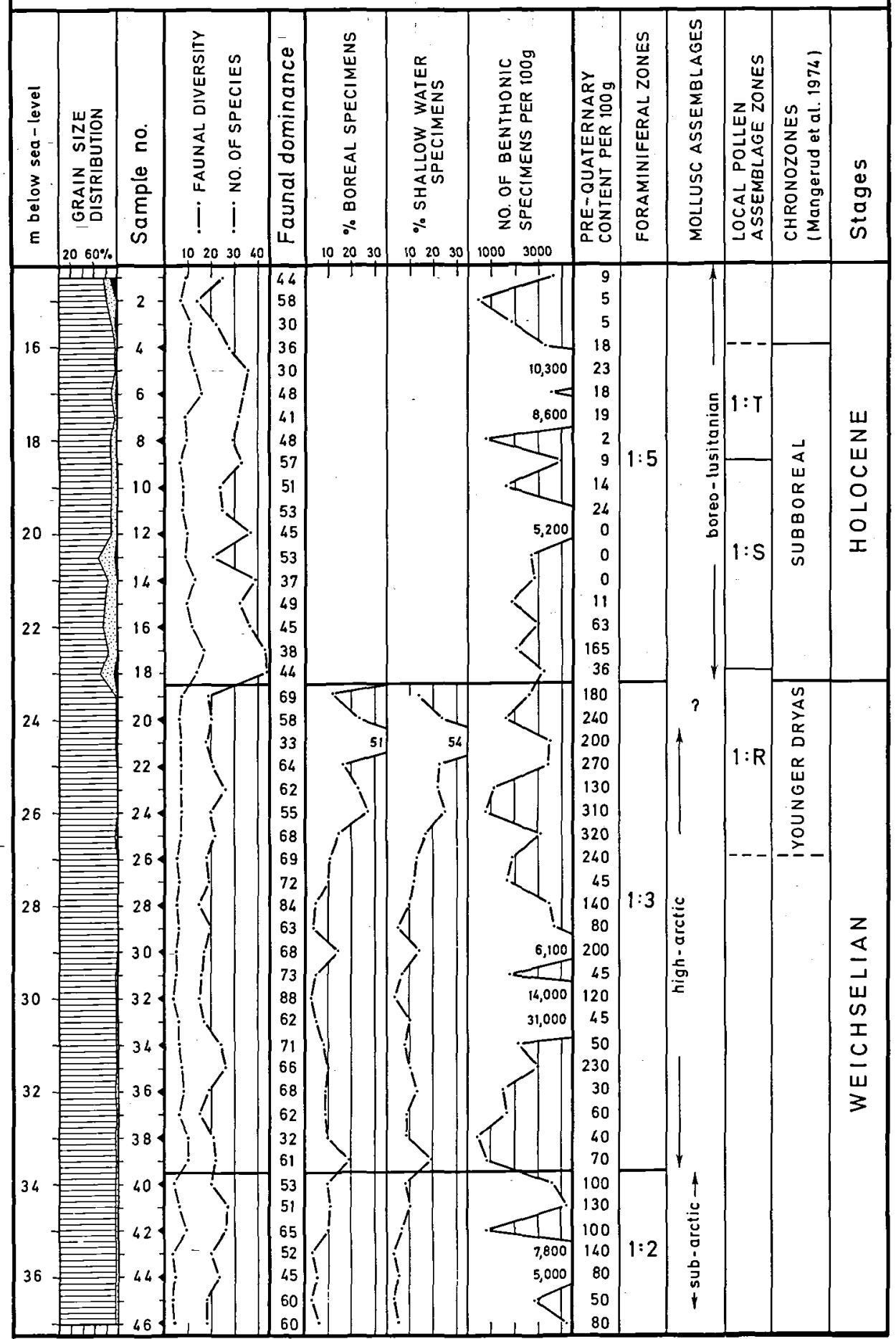

Fig. 5b. Frederikshavn 1, palaeoecological indices and correlation. Cored samples are marked with triangles. 


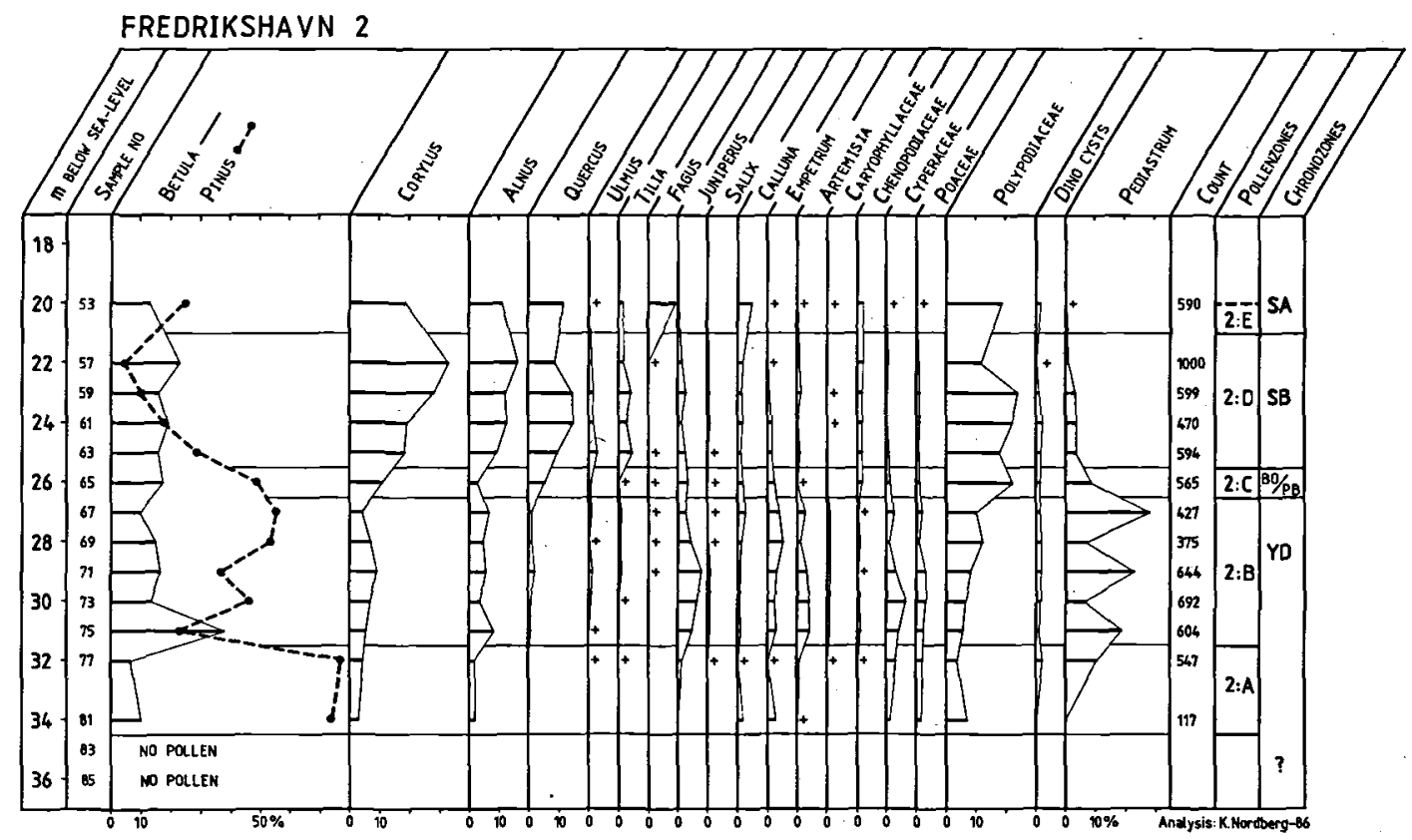

Fig. 6. Pollen diagram for Frederikshavn 2.

may represent Quaternary rebedded pollen and spores derived from outwashed and/or eroded glacial deposits. The zone is interpreted as belonging to the Younger Dryas Chronozone.

LPAZ 2:C Pinus-Corylus-Polypodiaceae (26/2725/26 m)

Pinus remains the dominant taxa in LPAZ 2:C, though there is a rise in Betula, Corylus, and Quercus. The Polypodiaceae curve rises abruptly at the base of the zone. The chronological interpretation of this zone is somewhat uncertain, but it seems to correspond to the Boreal or possibly the Preboreal Chronozone.

\section{LPAZ 2:D Corylus-Alnus-Quercus-Tilia-Polypo-} diaceae $(25 / 26-21 \mathrm{~m})$

The Pinus curve declines considerably in LPAZ 2:D. Betula, on the other hand, remains constant throughout and, .consequently, dominates over Pinus in the upper part of the zone. Corylus and Alnus continuously increase in relative importance and Quercus attains its maximum. Relatively high frequencies of Tilia are also apparent. The Polypodiaceae is a relatively constant and important element of all the assemblages. This zone is interpreted as belonging to the Subboreal Chronozone.

LPAZ 2:E Pinus-Quercus-Fagus-Calluna (20-21 m)

This zone is represented by one single analysis. Pinus rises again in importance, while Corylus falls, and Alnus and Quercus are relatively constant. Fagus passes its rational limit between samples 57 and 53. Calluna pollen also shows a rise. This zone belongs to the Subatlantic Chronozone.

\section{Frederikshavn 1 (fig. 7)}

This core shows a very similar vegetational succession to that described in Frederikshavn 2 (F2). The main difference is the lack of sediments representing the Boreal/Preboreal Chronozone and a more prolonged Fagus rise within Fl. There is also evidence to suggest very irregular accumulation rates, and at least one hiatus is present.

LPAZ 1:R Pinus-Betula-Artemisia (27-24/22 m) The zone is dominated by Pinus. Artemisia shows a slight fall upwards. Very high frequencies of 
Pediastrum occur. Corylus, Alnus, and Polypodiaceae are well represented.

This zone seems to correspond with zone $2: B$ in boring F2. The high values of Pediastrum may indicate a pronounced influence of fresh water. As in zone 2:B in F2, Corylus, Alnus, and Polypodiaceae may have been redeposited from older strata. Chronologically the zone belongs to the Younger Dryas.

LPAZ 1:S Corylus-Alnus-Quercus-Tilia-Polypodiaceae (24/22-19/18 m)

This zone is dominated by Corylus, Alnus, Quercus, and Tilia. Low values of Ulmus occur. Betula is relatively more important than Pinus. Polypodiaceae is abundant, but decreases in importance upwards. The zone is related to the Subboreal Chronozone.

\section{LPAZ 1:T Alnus-Quercus-Fagus-Calluna (19/18-} 16)

Quercus attains its maximum in this zone. Fagus becomes successively more common and reaches its rational limit between samples 8 and 4. Calluna, Chenopodiaceae, and Artemisia also show slight increases. This zone is, like LPAZ 1:S, assigned to the Subboreal Chronozone. The Subatlantic Chronozone is reached in the uppermost part of this zone (fig. 8).

\section{Mollusc contents}

Table 3 contains a list of molluscs registered in samples from the borings Frederikshavn 1 and 2 . The zoogeographical interpretations are made according to Antevs (1928). A brief interpretation of the environmental indications is shown in figs. $4 b$ and $5 b$.

\section{Foraminiferal list}

The species mentioned in the text are arranged alphabetically in table 4 . About 70 other species were found in low numbers in the samples, but these have been excluded from the discussion and from the list as they have no significance for the interpretation.

The species, which are included in calculating the boreal content are marked with a $B$, and shallow water species are marked with an $\mathrm{S}$.

\section{Summary and conclusions}

Combining the foregoing foraminiferal and pollen data, the Weichselian/Holocene boundary can be placed between foraminiferal zones 3 and 4 and between pollen zones $\mathrm{l}: \mathrm{R}$ and $\mathrm{l}: \mathrm{S}$ in boring 1 and $2: B$ and 2:C in boring 2 (fig. 8).

The foraminiferal faunas found in the lower

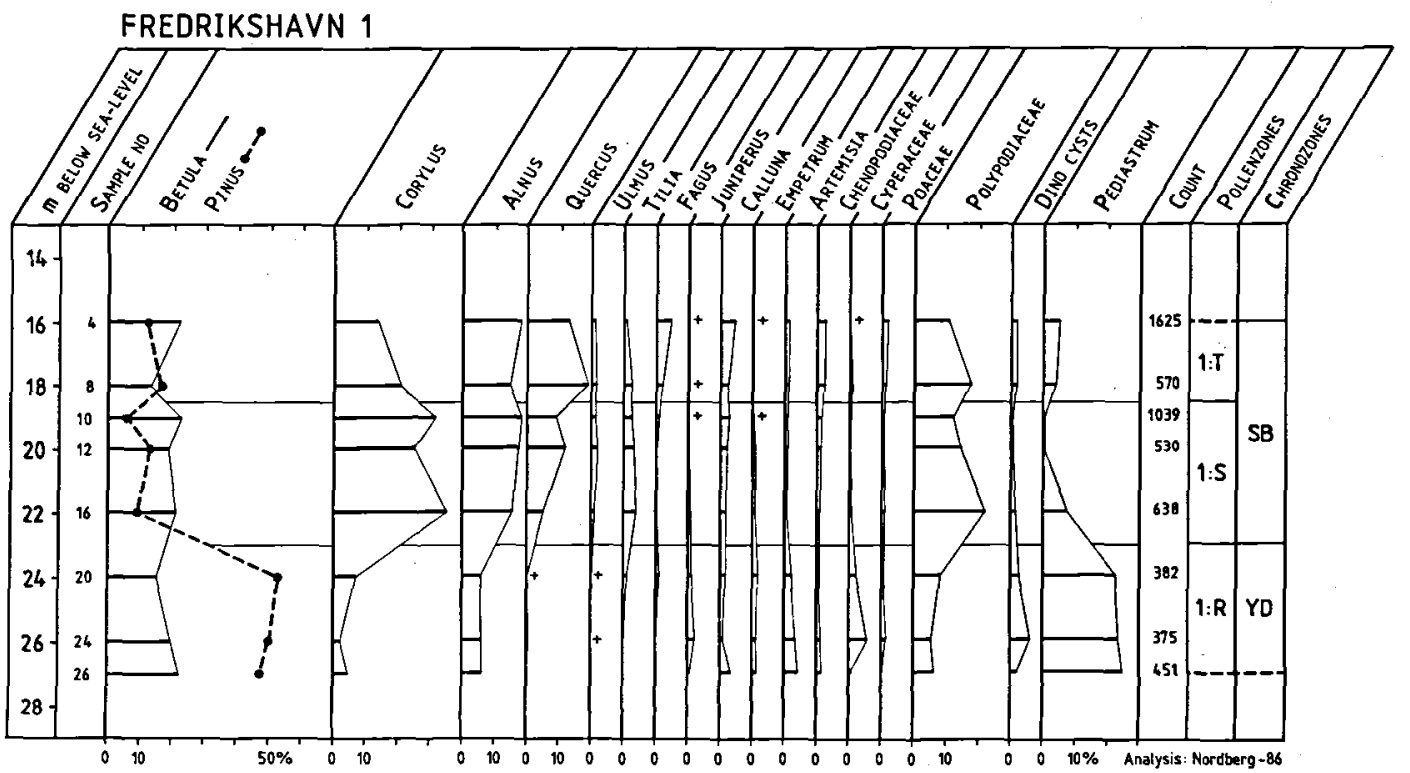

Fig. 7. Pollen diagram for Frederikshavn 1. 
Table 3. Molluscs in Frederikshavn 1 and 2

1. Arctic-Arctic/Boreal species:

Arctica islandica (Linné)

Astarte borealis (Schumacher)

Buccinum undatum Linné

Hiatella arctica (Linné)

Macoma calcarea (Chemnitz)

Modiolus modiolus (Linné)

Mya truncata Linné

Natica clausa Broderip and Sowerby

Nuculana minuta (Müller)

Nuculana pernula (Müller)

Portlandia arctica (Gray)

Trophon clathratus (Linné)

2. Boreal-Boreal/Lusitanian species:

Abra alba (Wood)

Abra nitida (Müller)

Acanthocardia echinata (Linné)

Aporrhais pespelicani (Linné)

Astarte sulcata (da Costa)

Cerastoderma edule (Linné)

Chlamys sp.

Corbula gibba (Olivi)

Cultellus pellucidus (Pennant)

Dosinia exoleta (Linné)

Littorina littorea (Linné)

Mangelia brachystomum (Phillippi)

Montacuta ferruginosa (Montagu)

Mysella bidentata (Montagu)

Mysia undata (Pennant)

Mytilus edulis Linné

Nassa incrassata (Ström)

Nassa pygmea (Lamarck)

Nassa reticulata (Linné)

Natica alderi Forbes

Natica montagui Forbes

Nucula nucleus (Linné)

Nucula sulcata Bronn

Onoba vitrea (Montagu)

Saxicavella jeffreysi Winckworth

Thyasira flexuosa (Montagu)

Thrritella communis (Risso)

Utriculus obtusus (Montagu)

Venus fasciata (da Costa)

Venus striatula (da Costa)

3. Climatically indifferent species:

Macoma balthica (Linné)

Nucula tenuis (Montagu)

Yoldiella lenticula (Möller)

part of both borings indicate relatively deep and arctic waters, but more ameliorated, shallower water conditions occurred at the top of zone 2 and in the zone 3 . The pollen evidence places the upper part of the Weichselian sequence within the Younger Dryas Chronozone. As no oscillations in environmental conditions are seen in the lower three foraminiferal zones, these must all belong to the Younger Dryas. If the Allerød or the Bølling Interstadial periods were present here, these would have been clearly indicated by ameliorated zones, as is seen for instance in $\mathrm{N}$. Jutland for the Bølling (Knudsen 1978) and in W.
Sweden for the Allerød (Knudsen 1982; Bergsten 1985).

In contrast to this, the sparce mollusc assemblages point to high-arctic conditions at the top of the Younger Dryas sequence (figs. $4 b$ and $5 b$ ), and to sub-arctic conditions prior to that. The foraminiferal indication of ameliorated conditions in this upper part is mainly caused by a rise in frequency of the two shallow water species Elphidium albiumbilicatum and E. magellanicum. If conditions were slightly ameliorated, which was presumably the case towards the end of the Younger Dryas, reduced salinity consequent on a shallowing in water depth may well be the main reason for such a faunal change.

The accumulation rate must have been considerable during the Younger Dryas, and it was even higher at boring 1 than at boring 2 (fig. 8). This interpretation is supported by the surprising lack

Table 4. Foraminifera in Frederikshavn 1, 2 and 3

Ammonia batavus (Hofker, 1951) - B - S

Astrononion gallowayi Loeblich and Tappan, 1953

Aubignyna cf. perlucida (Heron-Allen and Earland, 1913) - B S

Buccella frigida (Cushman, 1922)

Buccella frigida (Cushman), var. calida (Cushman and Cole, 1930) - B

Bulimina marginata d'Orbigny, 1826 - B

Cassidulina reniforme Nørvang, 1945

Cibicides lobatulus (Walker and Jacob, 1798)

Eggerella scabra (Williamson, 1858) - B

Elphidium albiumbilicatum (Weiss, 1954) - B - S

Elphidium asklundi, Brotzen, 1943 - S

Elphidium excavatum (Terquem), forma clavata Cushman, 1930

Elphidium excavatum (Terquem), forma selseyensis (HeronAllen and Earland, 1911) - B

Elphidium gerthi van Voorthuysen, 1957 - B - S

Elphidium hallandense Brotzen, 1943 - S

Elphidium incertum (Williamson, 1858) - B - S

Elphidium magellanicum Heron-Allen and Earland, 1932 - B S

Elphidium margaritaceum Cushman, 1930 - B - S

Hyalinea balthica (Schroeter, 1783) - B

Islandiella helenae Feyling-Hanssen and Buzas, 1976

Islandiella norcrossi (Cushman, 1933)

Nonion depressulum (Walker and Jacob, 1798) - B - S

Nonion germanicum (Ehrenberg, 1840) - B - S

Nonion labradoricum (Dawson, 1960)

Nonion orbiculare (Brady, 1881) - S

Nonionella turgida (Williamson, 1858) - B

Pyrgo williamsoni (Silvestri, 1923)

Quinqueloculina agglutinata Cushman, 1917

Quinqueloculina seminulum (Linné, 1758)

Stainforthia fusiformis (Williamson, 1858) - B

Stainforthia loeblichi (Feyling-Hanssen, 1954)

Stainforthia schreibersiana (Czjzek, 1848)

Textularia sagittula Defrance, 1824 - B 


\section{FREDERIKSHAVN}

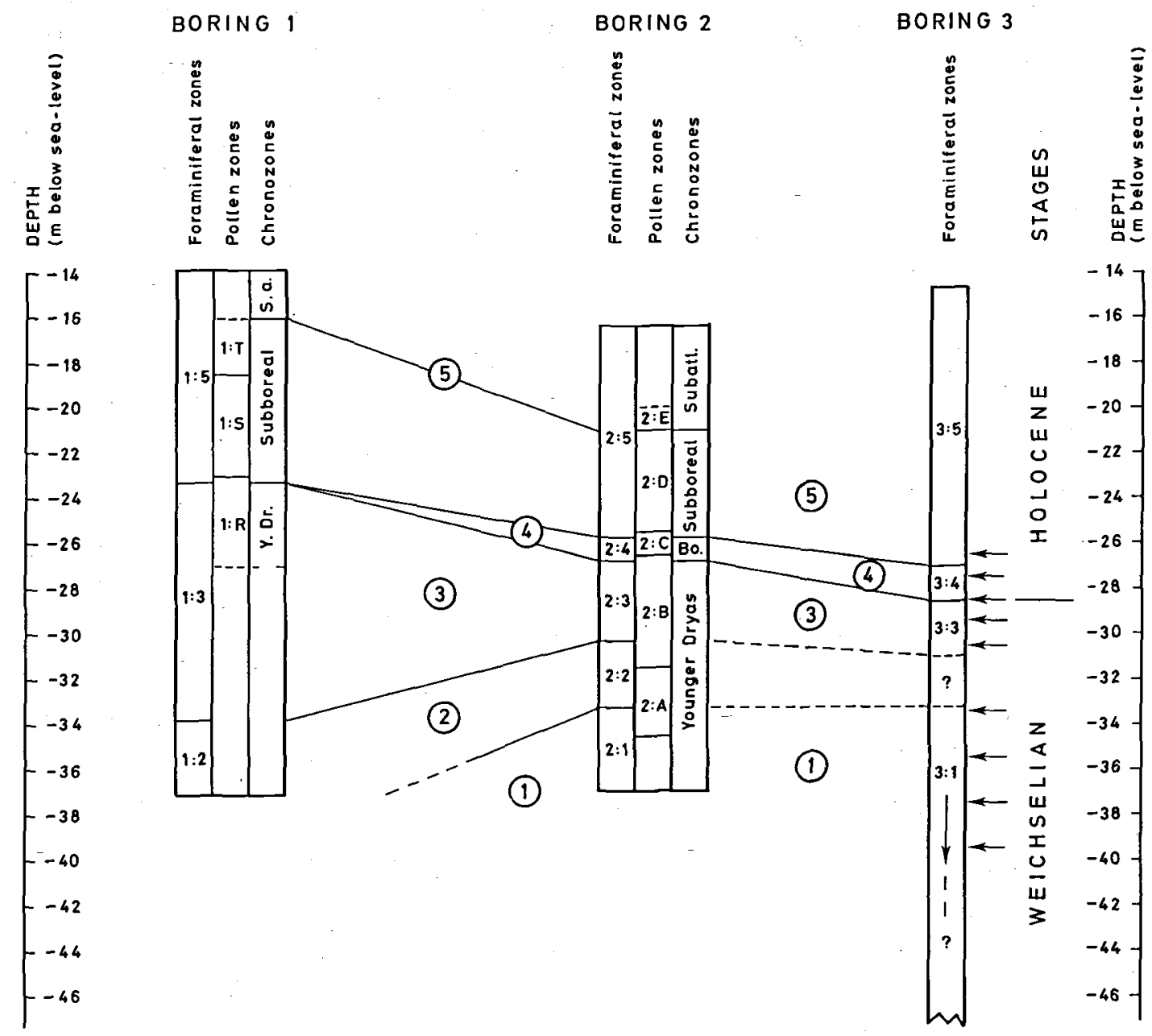

Fig. 8. Cross-correlation between the Frederikshavn 1, 2, and 3 borings (see fig. 2) based on foraminifera and pollen. Numbers $1-5$ refer to foraminiferal zones.

of pollen, even of reworked pollen, in the lower zones. Only pollen zones $2: B$ and $1: R$ contain a certain amount of both reworked pre-Quaternary material and of Quaternary pollen.

The relatively rapid accumulation of clay during the Younger Dryas off NE Jutland may have been caused by clay flocculation, where fresh sediment-loaded water from rivers to the south and southeast (see also Larsen et al. 1986) met the more saline waters of the North Sea. The influence of freshwater in the region is demonstrated by the presence of Pediastrum in the Younger Dryas floras here.

The Pediastrum curve clearly falls from pollen zone 2:B to $2: \mathrm{C}$ and from zone $1: \mathrm{R}$ to $1: \mathrm{S}$ (figs. 6 and 7). This change to a low influx of Pediastrum may have been caused by the presence of different water masses in the area. Prior to this the water supply was mainly from the east, southeast, and south, but it may have changed as North Sea waters entered from the north and northwest. Such a major shift in the circulation pattern around the Pleistocene-Holocene boundary has previously been discussed by e.g. Mörner (1984) and Björklund et al. (1985).

The foraminiferal assemblages in zone 4 of borings 2 and 3 at Frederikshavn seem to be mixed faunas. There is an increase in boreal taxa, 
though the arctic species present are the same as those found in zone 3 below. The arctic content here may partly be redeposited from older sediments after this major change in water circulation pattern at the Pleistocene-Holocene boundary.

The sediments fine upwards in the study area above the Pleistocene-Holocene boundary (figs. $4 b$ and $5 b$ ). This may illustrate the gradual building up of the Skagen Peninsula through the Holocene. The centre for sand sedimentation in the region has gradually moved northwards to its present position east of Skagen (Flodén 1973; Fält 1982).

A hiatus occurs between pollen zone $2: \mathrm{C}$ from the Boreal and zone 2:D in Frederikshavn boring 2 , as the latter contains Subboreal pollen spectra. Sediments from the Preboreal, Boreal, and Atlantic Chronozones are all lacking in boring 1 . Such a transition directly from the pre-Holocene to the Subboreal seems to be a common feature in the southern Kattegat area (Nordberg in prep.).

The lack of shallow water foraminiferal and mollusc faunas at the base of zone 5 in all the three borings at Frederikshavn indicates either a period of non-deposition or erosion prior to the deposition of zone 5 .

Comparison with the foraminiferal faunal succession in a Late Weichselian-Holocene sequence in the Skagerrak (Nagy and Qvale 1985) supports the palynological indication of an Early Holocene hiatus at Frederikshavn. In this Skagerrak core (Oskap, fig. 1) Hyalinea balthica does not occur in the lower part of the Holocene. It was supposed to have immigrated into the area during the Atlantic, slightly later than the establishment of the Norwegian Coastal Current, as indicated by the planktonic foraminifera (Thiede 1985). At Frederikshavn Hyalinea balthica occurs together with Bulimina marginata already from the bottom of zone 5 (figs. $4 \mathrm{a}$ and $5 \mathrm{a}$ ).

These two species also co-occurred at the base of the Holocene in Djupa Rannan in the eastern Kattegat and Skagerrak (Fält 1982). Early Holocene sediments may, therefore, be missing in that area as well.

There is a marked increase in Eggerella scabra at the top of the two Frederikshavn borings (figs. $4 a$ and 5a). A similar increase at the top of the Subboreal and in the Subatlantic has also been recorded in the western Baltic (Exon 1972), and it is known from the southern Kattegat as well (Nordberg and Bergsten in prep.). Exon (1972) connected this immigration with a period of increased salinity. E. scabra requires a salinity of at least $24 \%$ for most of the year (Lutze et al. 1983). The marked decline of $E$. scabra in the top sample of Frederikshavn 1 may correspondingly have been caused by a subsequent lowering in salinity. The previously mentioned problems concerning the preservation of $E$. scabra tests may, however, also play a role in its distribution (see foraminiferal stratigraphy).

The rise in Bulimina marginata in the uppermost sample of boring 2 corresponds to the faunal change observed in the surface sediments of the Oslofjord (Risdal 1963) and in the eastern Kattegat (Fält 1982).

Acknowledgements. We are grateful to Niels Foged, Danish Geotechnical Institute for placing sample material at our disposal and for valuable information and discussion during the work. Our sincere thanks to David N. Penney, Århus for critically reading the manuscript and for improving the English of the text. We also want to thank Svend Meldgaard and Robert Relfsson for processing the samples, Lissi $\emptyset$. Mogensen for arranging the manuscript and Jette Gissel Nielsen, who made most of the drawings. Permission to publish the present biostratigraphical results was obtained from Danish Geotechnical Institute and their clients. This is gratefully acknowledged.

\section{Dansk sammendrag}

Boringer $i$ havbunden sydøst for Frederikshavn indeholder aflejringer af Sen Weichsel og Holocæn alder. Disse sedimenter er undersøgt for indhold af foraminiferer, pollen og mollusker.

De marine sedimenter i bunden af boringerne indeholder arktiske til subarktiske faunaer (foraminiferzonerne 1-3, fig. 8). Hele denne nedre del af lagserien er henfort til Yngre Dryas, dels på grundlag af pollen-indholdet $i$ dens фvre del (zonerne $1: R, 2: A$ og 2:B, fig. 8), og dels fordi faunaerne under disse pollenzoner ikke viser tegn på marin-klimatiske variationer, der kunne tolkes som interstadiale perioder.

Mindst $14 \mathrm{~m}$ sediment er således dannet $\mathrm{i}$ løbet af Yngre Dryas sydøst for Frederikshavn. En så stor sedimentationshastighed kan muligvis skyldes flokkulation af lersedimenter. Det undersøgte område må have ligget meget tæt på den daværende nordspids af Jylland, og ferskvand fra floderne fra syd og sydøst har således netop her mødt Nordsøvand med normal marin salinitet.

Pleistocæn/Holocæn-grænsen er registreret i boringerne mellem 23,5 og 28,5 $\mathrm{m}$ under nuværende havniveau. Ved denne grænse forekommer et markant skift i flora og fauna, som viser, at nye vandmasser har præget området i Holocæn.

I alle boringerne forekommer en hiatus umiddelbart over foraminifer-zone 3. I en del af området har denne hiatus imidlertid kun varet af kortere varighed, idet en tynd zone $4 \mathrm{i}$ boringerne 2 og 3 kan henføres til Boreal tid (eller evt. sidste del af Præboreal tid).

Direkte over sedimenterne fra Yngre Dryas i boring 1 (fig. 8), og efter aflejringen af zone $4 i$ boringerne $2 \operatorname{og} 3$, findes en større afbrydelse af sedimentationen i hele området. De marine 
sedimenter i zone 5 er således henført til Subboreal og Subatlantisk tid på grundlag af pollen. En tilsvarende lakune forekommer ofte i det sydlige Kattegat-område. Foraminifer-faunaer fra boringer i den østlige del af Kattegat og i Skagerak tyder ligeledes på, at aflejringer af tidlig Holocæn alder kan mangle her.

\section{References}

Andersen, S. T. 1984: Forests at Løvenholm, Djursland, Denmark, at present and in the past. Biol. Skr. Dan. Vid. Selsk. , 24(1), 1-208.

Antevs, E. 1928: Shell beds on the Skagerrak. Geol. För. Stockholm Förh. , 50(4), 478-750.

Assarsson, G. and Granlund, E. 1924: En metod for pollenanalys av minerogena jordarter. Geol. För. Stockholm Förh. , $46,76-82$.

Berglund, B. E. 1966: Late Quaternary vegetation in eastern Blekinge, south-eastern Sweden. I, Late-Glacial time. II, Post-Glacial time. Opera Bot. , 12, I:1-180, II:1-190.

Berglund, B. E. 1969: Vegetation and human influence in South Scandinavia during Prehistoric time. Oikos suppl., 12, 9-28.

Bergsten, H. 1985: Biostratigrafisk analys av en lerlagerföljd från centrala Göteborg. Chalmers Tekniska Högskola/Göteborgs Universitet, Geologiska Institutionen, Publ. B264, $1-65$.

Björklund, K. R., Bjørnstrand, H., Dale, B. et al. 1985: Evolution of the Upper Quaternary depositional environment in the Skagerrak: A synthesis. Norsk Geol. Tidsskr. , 65, 139-149.

Buzas, M. A. 1965: Foraminifera from late Pleistocene clay near Waterville, Maine. Smithsonian Misc. Coll. , 145(8), $1-30$.

Erdtman, G. 1960: The acetolysis method. Svensk bot. Tidsskr., 54, 561-564.

Exon, N. 1972: Sedimentation in the outer Flensburg Fjord Area (Baltic Sea) since the last Glaciation. Meyniana, 22, $5-62$.

Feyling-Hanssen, R. W. 1972: The foraminifer Elphidium excavatum (Terquem) and its variant forms. Micropaleontology, 18(3), 337-354.

Feyling-Hanssen, R. W., Jørgensen, J. A., Knudsen, K. L. and Lykke-Andersen, A.-L. 1971: Late Quaternary Foraminifera from Vendsyssel, Denmark and Sandnes, Norway. Bull. geol. Soc. Denmark, 21(2-3), 67-317.

Flodén, T. 1973: Notes on the bedrock of the eastern Skagerrak with remarks on the Pleistocene deposits. Stockholm contr. geol. , XXIV, 79-102.

Fries, M. 1951: Pollenanalytisk vittnesbörd om senkvartär vegetationsutveckling, särskilt skogshistoria i nordvästra Götaland. Acta Phytogeographica Suecia, 29, 1-220.

Fält, L.-M. 1982: Late Quaternary sea-floor deposits off the Swedish west coast. Chalmers Unversity of Technology/ University of Gothenburg, Dept. of Geology, Publ. A37, $1-259$.

Hedberg, H. D. (ed.) 1976: International stratigraphic guide. A guide to stratigraphic classification, terminology and procedure, 1-200. Wiley and Sons, New York.
Heusser, L. E. 1983: Pollen distribution in the bottom sediments of the Western North Atlantic Ocean. Marine Micropaleontology, 8, 77-88.

Iversen, J. 1967: Naturens udvikling siden sidste Istid, 345-445. In: Nörrevang, A. and Meyer, T. J. (eds.). Danmarks Natur I. Politikens Forlag, Copenhagen.

Knudsen, K. L. 1978: Middle and Late Weichselian marine deposits at Nørre Lyngby, northern Jutland, Denmark, and their foraminiferal faunas. Danm. geol. Unders. , II række, 112, 1-45.

Knudsen, K. L. 1982: Foraminifers, 148-177. In: Olausson, E. (ed.). The Pleistocene/Holocene boundary in south-western Sweden. Sveriges geol. Unders. C 794.

Larsen, G., Baumann, J. and Bjørn, O. 1986: Kvartærgeologiske forhold under havbunden i Lasø Rende. Dansk Geol. Foren., Arsskrift for 1985, 39-46.

Lutze, G. F. 1965: Zur Foraminiferen-Fauna der Ostsee. Meyniana, 15, 75-142.

Lutze, G. F., Mackensen, A. and Wefer, G. 1983: Foraminiferen der Kieler Bucht: 2 Salinitätsansprüche von Eggerella scabra (Williamson). Meyniana, 35, 55-65.

Mangerud, J., Andersen, S. T., Berglund, B. E. and Donner, J. J. 1974: Quaternary stratigraphy of Norden, a proposal for terminology and classification. Boreas, 3, 109-128.

Mangerud, J. and Berglund, B. E. 1978: The subdivision of the Quaternary of Norden: a discussion. Boreas, 7, 179-181.

Meldgaard, S. and Knudsen, K. L. 1979: Metoder til indsamling og oparbedning af prøver til foraminiferanalyser. Dansk Natur Dansk Skole, Arsskrift 1979, 48-57.

Mörner, N.-A. 1969: The Late Quaternary history of the Kattegatt Sea and the Swedish west coast. Deglaciation, shorelevel displacement, chronology, isostacy and eustacy. Sveriges geol. Unders. C 640, 1-487.

Mörner, N. -A. 1984: Climatic changes on a yearly to millenial basis. Concluding remarks, 637-651. In: Mörner, N.-A. and Karlén, W. (eds.). Climatic Changes on a Yearly to Millenial Basis. Reidel Publishing Company, Dordrect, Boston, Lancaster.

Nagy, J. and Qvale, G. 1985: Benthic foraminifers in Upper Quaternary Skagerrak deposits. Norsk Geol. Tidsskr. , 65, 107-113.

Nordberg, K. 1986: Pollen - Ett användbart stratigrafiskt verktyg i södra Kattegatts holocena sediment. 17:e Nordiska Geologmötet. Abstracts. Helsingfors universitet.

Påsse, T. 1985: Cotton wool filtering for pollen enrichment. Geol. För. Stockholm Förh. , 106, 275-277.

Risdal, D. 1963: Foraminiferfaunaen i en del sedimentkjerner fra indre Oslofjord (The Foraminiferal fauna in some cores from inner Oslo Fjord). Norges geol. Unders. , 224, 1-90.

Robertsson, A.-M 1982: Pollen, 224-242. In: Olausson, E. (ed.). The Pleistocene/Holocene boundary in south-western Sweden. Sveriges geol. Unders. C 794.

Stanley, B. A. 1966: The problem of reworked spores and pollen in marine sediments. Marine Geology, 4, 397-408.

Thiede, J. 1985: Planktonic foraminifers in Upper Quaternary marine Skagerrak sediments. Norsk Geol. Tidsskr. , 65, $115-118$.

Walton, W. R. 1964: Recent foraminiferal ecology and paleoecology, 151-237. In: Imbrie, J. and Newell, N. D. (eds.). Approaches to Paleoecology. Wiley and Sons, New York. 